J. Clin. Chem. Clin. Biochem.

Vol. 26,1988 , pp. $479-489$

(C) 1988 Walter de Gruyter \& Co. Berlin - New York

\title{
The Biological Effects of Retinoids on Cell Differentiation and Proliferation
}

\author{
By L. Favennec
}

Laboratoire de Biochimie, Groupe Hospitalier Pitié-Salpétrière, Paris, France and

M.-J. Cals

Laboratoire de Biochimie, Hôpital Corentin-Celton, Issy-les-Moulineaux, France

Laboratoire de Biochimie, CNRS UA 622, Université Paris XI, Chatenay-Malabry, France

(Received June 1, 1987/February 29, 1988)

Summary: The retinoids are the natural and synthetic analogues of retinol or vitamin A. These molecules are able to modulate differentiation and proliferation processes in several cell types. The presence of retinoids is essential for inducing or maintaining the differentiation of epithelial cells. On the other hand, when excess retinol is added to the culture medium, the differentiation of some mesenchymal cells is impaired. Retinoids also promote the differentiation of carcinoma cells of various origins: embryonal carcinoma, leukaemic and melanoma cells. While their effect on the proliferation of normal cells appears variable, these molecules inhibit the growth of cells treated with a tumoural promoter, or spontaneously transformed cells, and they prevent tumour promotion. Various mechanisms of action might be involved: retinoids could act at the level of the genome with or without the participation of their binding proteins. They might also influence glycoconjugate biosynthesis and interact, through certain glycosylation reactions, with growth factor receptors. The role of vitamin A and its structural analogues in cell differentiation and growth is of great therapeutic interest.

\section{Introduction}

The neoplastic process is characterized by an alteration of the differentiated histological state of cells towards metaplastic and anaplastic forms and is associated with cellular proliferation which escapes the usual homeostatic control systems.

While cancerology has been concerned essentially with the treatment of clinically detectable forms of neoplastic disease, numerous studies are being carried out at present aimed at identifying substances which might be able to act before the neoplastic process becomes invasive, i.e. to act on the differentiation and proliferation processes of the cells concerned. One of these substances, vitamin $\mathrm{A}$ - and its derivatives, the retinoids - has been studied extensively and we propose a review of the relevant work.
After a brief reminder of the structure and metabolism of the retinoids we shall go on to discuss first the effect of these compounds on the differentiation of various cell types (of epithelial, mesenchymal and cancerous origin). We shall then study the influence of the retinoids on the proliferation of normal and cancerous cells and those treated by promoters. Finally, we shall discuss the various modes of action which have been suggested.

\section{The Retinoids: Structure and Metabolism}

Lotan (1) defines as 'vitamin A' or retinoids a group of substances capable of restoring normal growth in retinol-deficient experimental animals. The general formula of these compounds comprises a cyclic struc- 
ture, a central polyenic chain and a polar terminal group. The most frequently used molecules, natural or synthetic, are described in figure 1.

\section{Absorption and transport}

The natural retinoids are ingested in the food in the form of retinol, retinyl esters, retinoic acid and a provitamin, $\beta$-carotene. The retinyl esters are hydrolysed by enzymes ${ }^{1}$ ) present in the pancreas and brush border membrane; retinol and carotene are then absorbed by the intestinal mucosa. In the enterocytes, $\beta$-carotene is split into two molecules of retinal which are then reduced; the retinol is reesterified and the retinyl esters incorporated into the chylomicrons. The latter are then degraded into remnants and captured by the liver. The retinyl esters are stored in the hepatocytes and perisinusoidal cells (2) and hydrolysed according to the requirements of the organism. The retinol is then transported towards the tissues in the form of a circulating complex associating retinol, transthyretin and retinol binding protein (3). Retinol binding protein consists of a polypeptide chain of $M_{\mathrm{r}}=21000$ and possesses a binding site for retinol. In the plasma, one molecule of retinol binding protein associates with one molecule of transthyretin, a symmetrical tetramer composed of 4 identical subunits, each of molecular weight 55000 and possessing a binding site for retinol binding protein. Under physiological conditions, the transthyretin/retinol binding protein ratio is a constant $2.5 / 1$ in the plasma and nearly all the circulating retinol binding protein is bound to transthyretin.

Retinyl esters are only present in very low concentrations in the plasma, but if intake is excessive and the liver storage capacity becomes saturated, the retinyl esters circulate bound to lipoproteins.

Finally, retinoic acid and its structural analogues are transported, following absorption, by the portal vein. They are not stored but circulate in the plasma bound to serum albumin.

\footnotetext{
1) Enzymes

- Alcohol dehydrogenase (EC 1.1.1.1)

- Cholinesterase

(EC 3.1.1.8)

- Epoxidase

(EC 3.3.2.3)

- Fucosyl transferase

(EC 2.4.1.68)

- Galactosyl transferase (EC 2.4.1.38)

- Glycosyl transferase (EC 2.4.1.24)

- Ornithine decarboxylase(EC 4.1.1.17)

- Protamine kinase (EC 2.7.1.70)

- Protein kinase (EC 2.7.1.37)

- Sialyl transferase

(EC 2.4.99.1)

- Tyrosinase

(EC 1.10.3.1)
}
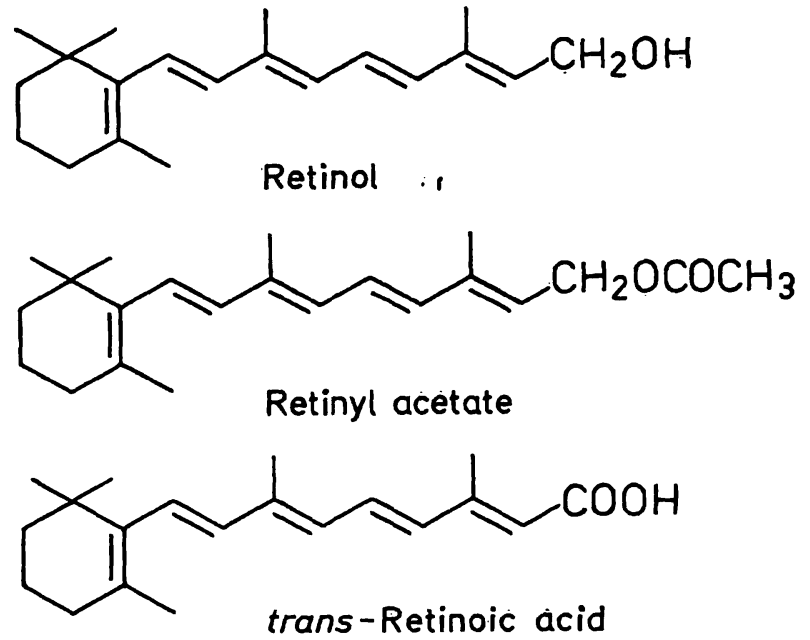<smiles>CCOC(=O)C=C(C)C=CC=C(C)C=Cc1c(C)cc(OC)c(C)c1C</smiles>

Fig. 1. Principle retinoids studied

\section{Capture and intracellular transport}

Retinol binding protein binds to specific membrane receptors: the retinol then passes into the cell and the retinol binding apoprotein is released (4). The cell transport mechanism of the other retinoids is little known.

In the cytosol retinol binds to a specific protein, cellular retinol binding protein present in several cell types. A cytosolic receptor for retinoic acid, cellular retinoic acid binding protein is also present in several organs in man and animals. Cellular retinoic acid binding protein is, however, less widely distributed than cellular retinol binding protein and the cellular retinol binding protein/cellular retinoic acid binding protein ratio varies greatly from one type of tissue to another (2).

Cellular retinol binding protein and cellular retinoic acid binding protein receptors have been detected and quantified through their ability to bind $\left[{ }^{3} \mathrm{H}\right]$ retinol and $\left[{ }^{3} \mathrm{H}\right]$ retinoic acid. By way of an example, the concentrations of cellular retinol binding protein found in various organs of humans and rats are given in table 1. The presence of specific cellular receptors for retinol and retinoic acid has also been described in certain neoplastic tissue, notably in tumours of the skin, breast and colon and in human and murine embryocarcinomas. Kung (5), Ong (6), Mchllcl (7) and "Palan (8) have found larger quantities of binding protein in cancerous tissue than in normal tissue (cellular retinoic acid binding protein: 5.6 and $35.0 \mathrm{mmol} /$ 
Tab. 1. Amounts of cellular retinol binding protein (CRBP) in various organs of man and the rat $(6,7)$.

\begin{tabular}{lrr}
\hline Organ & \multicolumn{2}{c}{ CRBP $(\mu \mathrm{g} / \mathrm{g}$ protein) } \\
\cline { 2 - 3 } & Man & Rat \\
\hline Testicle & 847 & 88 \\
Ovary & 1226 & 26 \\
Liver & 243 & 97 \\
Kidney & 67 & 115 \\
Lung & 41 & 76 \\
Spleen & 53 & 21 \\
Heart & 27 & 8 \\
Brcast & 19 & \\
Skin & 16 & 4 \\
Smooth muscle & 9 & 15 \\
\hline
\end{tabular}

$\mathrm{mg}$ of protein in normal and cancerous tissue respectively, from the rat mammary gland). In addition, Sklan \& Lotan (9) have shown the presence of a high molecular weight lipoprotein aggregate bearing both retinol and retinoic acid in the cytosol of various human and murine tumour cells.

Neither cellular retinol binding protein nor cellular retinoic acid binding protein show tissue specificity. These molecules have similar molecular weights (cellular retinol binding protein: $M_{\mathrm{r}}=14600$, cellular retinoic acid binding protein: $M_{\mathrm{r}}=14000$ ) and are composed of a single protein chain. Their composition is similar in terms of the amino acids they contain and certain sequences are shared. They are, however, immunologically different from each other and from plasmatic retinol binding protein. Cellular retinol binding protein possesses a high affinity for retinol and its cis-isomers $\left(\mathrm{K}_{d}=16 \times 10^{-9} \mathrm{~mol} / \mathrm{l}\right)$, but not for retinal and retinoic acid. One receptor molecule binds one ligand molecule. Similarly, cellular retinoic acid binding protein binds retinoic acid with a high specificity and affinity. The dissociation constant is approximately $10^{-8}$ to $10^{-9} \mathrm{~mol} / \mathrm{l}$.

The work of Takase et al. (10) on nuclei isolated from the liver of rats deficient in receptors has shown the presence of a specific and saturable bond between the $\left[{ }^{3} \mathrm{H}\right]$ retinol-cellular retinol binding protein complex and such nuclei. In contrast, the binding of free $\left[{ }^{3} \mathrm{H}\right]$ retinol in the same experimental conditions is nonspecific and nonsaturable. Experiments with $\left[{ }^{3} \mathrm{H}\right]$ retinoic acid-cellular retinoic acid binding protein and isolated nuclei of several cell models also show specific interactions between the retinoid-receptor complex and certain sites of the nucleus (11). These results suggest that following the formation of the retinoid-receptor complex there is a phenomenon of translocation of the cytosol towards certain specific sites of the nucleus which are distinct for the two molecules. The retinoids would then dissociate from their binding proteins. Moreover, very recently, using a cell line from a mammary carcinoma, MCF7, Petkovich et al. (12) cloned a cDNA located on chromosome 17 encoding a nuclear protein receptor that binds retinoic acid, but not retinol, with high affinity. However, the way in which cellular retinoic acid binding protein and this human retinoic acid receptor (hRAR) participate in the mechanism of action of retinoic acid remains undetermined.

\section{Intracellular metabolism}

Retinol can follow various metabolic pathways, whether or not it is bound to cellular retinol binding protein. It can first be converted to a glucuronoconjugate in the presence of UDP glucuronate. Retinol can also form esters and undergo dehydration giving rise to anhydroretinol. Finally, it can be oxidized into retinal in a reversible fashion, then irreversibly into retinoic acid; the reaction is catalysed by alcohol dehydrogenase in the presence of $\mathrm{NAD}^{+}$. The capacity of a cell to produce retinoic acid depends on the cell type and the experimental conditions (13). Napoli (14) showed that porcine kidney cells are able to generate retinoic acid from retinol. This property was not observed in similar experiments with certain lines of embryocarcinoma cells (15).

Retinoic acid is itself degraded in the microsomes (14). Its metabolism is complex: under the effect of an epoxidase, it forms a 5,6-epoxyretinoic acid which is then transformed into a 5,8-oxo derivative. Finally, retinoic acid can undergo various oxidative reactions, forming oxo and hydroxylated derivatives found in the urine and stools.

\section{Effects of Retinoids on the Differentiation of Normal and Cancerous Cells}

\section{Epithelial cells}

Vitamin A and its structural analogues play an important role in the establishment and maintenance of the differentiation of epithelial cells as shown both in vivo by experiments in healthy and deficient animals and in vitro using cultures of cells or explants in media lacking or supplemented with retinol.

In vivo - The study of goblet cells from normal or vitamin A-deficient rats

Rojanapo (16) and Olson (17) studied the differentiation of germ cells in fragments of the duodenal crypt glands of control and vitamin A-deficient rats. In 
normal conditions these cells migrate along the crypt gland while transforming into oligomucous cells and subsequently into mucus-producing goblet cells. A defiency in vitamin A produces a $35 \%$ reduction in the number of goblet cells from the fourth day onwards. The authors also observed a reduction in the incorporation of $\left[{ }^{14} \mathrm{C}\right]$ fucose into the glycoproteins of the deficient animals.

In vitro - Morphological studies of cells cultured in the presence or absence of retinol

Using tracheal explants from female rats, the authors show (18) that in the absence of vitamin $A$, the tracheal epithelium eventually acquires a squamous aspect and begins to produce large quantities of keratin, whereas explants maintained in normal medium containing a volume fraction of 0.1 horse serum, i.e. $48 \times 10^{-9} \mathrm{~mol} / \mathrm{l}$ of retinol show no signs of squamous metaplasia and are either ciliated or not. In retinol supplemented medium $\left(7 \times 10^{-6} \mathrm{~mol} / \mathrm{l}\right)$, the epithelium is hyperplasic and shows increased secretory activity (with an increased number of secretory granules). Experiments conducted by Hardy (19) on explants of fetal mouse skin showed that the normal differentiation of the epidermis was altered by the presence of excess retinol in the culture medium: on the tenth day, in the presence of $21 \times 10^{-6} \mathrm{~mol} / 1$ of retinol, the basal lamella is discontinuous, the corneal layer shows vacuoles, and the desmosomes and tonofilaments are greatly reduced in number. The keratinization process of new-born Balb/C mouse epidermal cells is also inhibited when the culture medium contains excessive amounts of retinyl acetate $\left(38 \times 10^{-6}\right.$ $\mathrm{mol} / \mathrm{l})(20)$.

It therefore appears that the absence of retinol favours squamous metaplasia: keratinized cells replace secretory cells (21). There is also an increase in mitotic activity. These factors favour the development of neoplastic lesions. However, while the retinoids are essential to the maintenance of normal differentiation, an excess of retinol in the culture medium of cutaneous epithelia inhibits the keratinization process and causes an overall disorganization of the cells which attain a certain degree of mucous metaplasia.

\section{Mesenchymal cells}

The effects of a lack or excess of vitamin A have been studied on the bone and cartilage of various animals $(22,23)$. A lack of retinol inhibits the differentiation of the osteoclasts but does not reduce osteoblastic activity. An excess of vitamin A appears to increase the resorption of the cartilage, thus increasing the risk of fracture.
In organ culture experiments, high doses of vitamin A lead to the destruction of the tracheal cartilage in hamsters (24) and of the articular cartilages in pigs (25) (due to the synthesis and release of lysosomal enzymes which destroy the extracellular matrix). The addition of $9.6 \mu \mathrm{mol} / \mathrm{l}$ of retinoic acid to the culture medium of mouse embryo mesenchymal cells (26) inhibits the formation of cartilage: on the fourth day, the cells, which remain closely packed together - the extracellular spaces contain fine bands of collagen retain the cytoplasmic characteristics of pre-cartilagenous cells. This inhibitory effect, which could be mediated by cellular retinoic acid binding protein, is not due to a toxic effect of retinoic acid, as shown by the study of cell viability by the trypan blue exclusion technique. Pennypacker (27) observed a decrease in proteoglycan synthesis in cultures treated with retinoic acid, accompanied by an increase in the glycosylation of cell surface glycoproteins.

Several lines of evidence corroborate the view that in the chick embryo limb bud, retinoic acid could act as a morphogen (28). Morphogens are the signal substances to which cells respond, at varying concentrations, by adopting different pathways of differentiation. Saunders \& Gasseling (29) showed that the posterior margin of the chick embryo limb bud grafted to the anterior side induced the development of a second set of digits symmetrical to the original set. This grafted zone, called the zone of polarizing activity (ZPA), is thought to diffuse a morphogen metabolised by the competent tissue, thus forming a concentration gradient. Retinoic acid, which forms a concentration gradient across the limb bud (30), could be the local chemical mediator since exogenous retinoic acid produces duplications exactly like ZPA grafts. The endogenous retinoic acid could be synthesized from retinol which does not present morphogenic properties. The cellular retinoic acid binding protein found in the ZPA at a concentration of $10^{-5}$ molecules per limb bud cell might mediate the effects of retinoic acid. However, the biochemical mechanism of the action of retinoids as morphogens has not yet been elucidated. The retinoid could be the first step in the morphogen response.

\section{Embryonal carcinoma cells}

These are the undifferentiated stem cells in teratocarcinoma. Several lines of embryonal carcinoma cells (EC cells) of murine and human origin have been isolated and cultured (31). The F9 cell line of teratocarcinoma cells undergoes only limited spontaneous differentiation under normal culture conditions. According to Strickland \& Mahdavi (32), retinoic acid 
$\left(10^{-6}\right.$ to $\left.10^{-9} \mathrm{~mol} / \mathrm{l}\right)$ is capable of inducing the differentiation of embryonal carcinoma cells of the murine cell-line F9: following 7 days' incubation in the presence of retinoic acid, the cells acquire an endodermic morphology and synthesize new forms of collagen. The membrane antigen SSE A1, characteristic of murine embryo carcinoma cells and revealed by immunofluorescence in the presence of monoclonal antibodies, disappears from almost all the cells after 7 days' treatment. Retinoic acid treatment $(0.1 \mu \mathrm{mol} / \mathrm{l})$ of F9 cells also causes a progressive increase in cytosolic and plasma membrane cyclic AMP-dependent protein kinases (33). Furthermore, dibutyryl cAMP treatment of endoderm-like cells generated by retinoic acid enhances the synthesis of basement membrane components such as laminin and collagen IV. Wang \& Gudas (34), using blot hybridization techniques showed that retinoic acid causes an increase in laminin B mRNA levels. $\beta_{2}$ Microglobulin, not synthesized by undifferentiated cells, was used by Eriksson et al. (35) to estimate the change in the phenotype of the retinoic acid-treated F9 cells. The amount of $\beta_{2}$ microglobulin found in the cell medium increases with the concentration of retinoic acid $\left(10^{-6}\right.$ to $\left.10^{-10} \mathrm{~mol} / \mathrm{l}\right)$ but not with retinol used in the same concentration range. The expression of $\beta_{2}$ microglobulin has been examined in F9 cells: no $\beta_{2}$ microglobulin mRNA is detected in undifferentiated cells, but it becomes detectable during differentiation. Other changes in gene expression have been demonstrated during the F9 differentiation process: Griep \& DeLuca (36) have examined the action of retinoic acid on the expression of the oncogene c-myc - this gene is known to be amplified in HL 60 cells. Its expression is decreased after retinoic acid-induced differentiation: the authors observed a $46 \%$ decrease in c-myc mRNA in F9 cells 3 hours after retinoic acid treatment.

Many studies have demonstrated that retinoic acid is more efficient than retinol in changing the F9 phenotype. The greater hydrophobicity of retinol would explain its binding to lipid bilayers and thus the difference in the capacity of the two retinoids to induce differentiation. However, undifferentiated F9 cells contain low concentrations of the two retinoid binding proteins, cellular retinol binding protein and cellular retinoic acid binding protein. Retinoic acid treatment promotes the intracellular accumulation of cellular retinol binding protein and cellular retinoic acid binding protein (35); thus, increased levels of retinoid binding proteins would reflect the novel phenotype of F9 differentiated cells. Cells of the murine line PCC4 aza $1 \mathrm{R}$, the so-called 'pluripotent' and nulli SCCI, or 'nullipotent' cells, i.e. incapable of undergoing spontaneous differentiation, proliferate and form aggre- gates when tissue culture dishes are previously coated with a solution of $2 \%$ agarose. Jetten et al. (37) and Sherman (38) observed a certain maturation induced by retinoic acid $\left(10^{-5}\right.$ to $\left.10^{-9} \mathrm{~mol} / \mathrm{l}\right)$ : certain nulli SCCI cells grown in aggregates became differentiated, and the proportion of aggregates containing differentiated pluripotent cells increased. The retinoic acid effect is concentration-dependent; the viability of the cells has been verified. Furthermore, the authors detected plasminogen activator production by differentiated cells after 2 days' incubation with retinoic acid: $36 \%$ of aggregated nulli SCCI cells acquire plasminogen activator activity. In response to retinol, nulli SCCI cells differentiate to a modest extent and PCC4 aza $1 \mathrm{R}$ not at all; moreover, retinol is toxic for PCC4 aza $1 \mathrm{R}$ cells at a higher concentration than $10^{-7} \mathrm{~mol} / \mathrm{l}$ for a few days.

Sherman (39) used a technique for the transplantation of control and retinoic acid-treated carcinoma cells into mice and observed no external sign of tumour growth in six of eight mice injected with retinoidtreated PCC4 aza 1 R cells, even after 100 to 200 days. Palpable tumours appeared in all eight mice receiving control cells within 10 to 12 days. Finally, mice were inoculated into the flank with $10^{6}$ to $6 \times 10^{6}$ PCC4 aza I cells then treated by 10 daily $20 \mu \mathrm{l}$ intra-tumoural injections of all-trans retinoic acid $(0.6 \mu \mathrm{mol} / \mathrm{l})$ dissolved in dimethylacetamide (40): on day 11, the treated tumours showed nearly complete differentiation into mainly fibrillar neuroepithelium.

Retinoic acid-induced differentiation of nulli SCCI and PCC4 aza 1R EC cells is mediated by cellular binding proteins. Translocation of binding protein molecules from cytoplasm to nucleus in response to the uptake of retinoids by the cell has been demonstrated by the detection of binding activity in nuclear fractions (41). When retinoic acid and retinol are introduced through their binding proteins, they bind to EC nuclei in a specific and saturable manner. Thus, the binding of $\left[{ }^{3} \mathrm{H}\right]$ retinoic acid-cellular retinoic acid binding protein to EC nuclei is maximal after $30 \mathrm{~min}$ and stable for two hours (41). Specific binding of $\left[{ }^{3} \mathrm{H}\right]$ retinol-cellular retinol binding protein appears to be slower. If cytosolic and nucleosolic fractions from untreated nulli SCCI cells contain little retinoic acid or retinol binding activity, exposure of cells to retinoids for two hours produces an increase in nuclear and cytosolic retinoic acid or retinol binding capacity.

Embryonal carcinoma cells of human origin derived from the cell line Tera 2 have been also studied: they possess a cell surface antigen SSEA 3 which can be revealed by immunofluorescence. Andrew's (42) used this antigen as a marker of non-differentiation. Of 
the cells treated with $10 \mu \mathrm{mol} / 1$ retinoic acid for 2 to 10 days, the proportion of non-differentiated fluorescent cells fell to less than $20 \%$.

Retinoic acid is therefore capable of inducing certain morphological and biochemical modifications in undifferentiated embryonic cells characteristic of the differentiated state. It is interesting to note that the concentration of retinoic acid required to induce differentiation in human cells $\left(10^{-5}\right.$ to $\left.10^{-6} \mathrm{~mol} / \mathrm{l}\right)$ is higher than in cells of murine origin $\left(10^{-7} \mathrm{~mol} / \mathrm{l}\right)$.

\section{Leukaemic cells}

Various lines of leukaemic cells are capable of differentiating in vitro in the presence of retinoic acid. The cellular source and experimental conditions used are given in table 2. This differentiation can be assessed by the following methods:

- morphological examination of cultures of promyelocytic leukaemic cells,

- assessment of the capacity for phagocytosis - a process characteristic of mature cells. Phagocytic cells induce oxidase synthesis, which in turn produces a superoxide anion able to reduce nitro blue tetrazolium (NBT),

- evaluation of haemoglobin synthesis,

- measurement of cholinesterase activity on cell homogenate,

- measurement of glycosyltransferase activities. These enzymes are essential to the synthesis of the cell surface glycoproteins which play an important role in cell differentiation - in particular by restoring contact inhibition.
Garg et al. (43), working on a murine erythroleukaemia cell line have shown that in culture and under the influence of $10 \mu \mathrm{mol} / \mathrm{l}$ retinoic acid, such cells differentiate into normoblasts. Their differentiation is characterized by an increase in the synthesis of haemoglobin ( 8 to $10 \mu \mathrm{g} / 10^{6}$ treated cells as opposed to 0.3 to $0.8 \mu \mathrm{g} / 10^{6}$ control cells) and an increase in cholinesterase activity. Flynn et al. (44) have described the effect of 13-cis-retinoic acid on cells taken from a patient suffering from acute promyelocytic leukaemia: $10^{-6} \mathrm{~mol} / 1$ retinoic acid induced the maturation of promyelocytes into myelocytes, metamyelocytes and mature polynuclear cells as shown by the microscopic examination of treated cultures. The proportion of cells able to reduce NBT is $90 \%$ in treated cultures and $15 \%$ in control cultures. The percentage of polynuclear cells was higher when the patient received pretreatment with retinoic acid $\left(0.3 \times 10^{-3}\right.$ $\mathrm{mol} / \mathrm{m}^{2} \cdot$ day). Finally, the cell line HL 60 (promyelocytes of human leukaemic origin and maintained in culture) is frequently used in studies of cell differentiation $(45-48)$. The proportion of phagocytic cells in the cell line HL 60 increases with the concentration . of retinoic acid $\left(10^{-8}\right.$ to $\left.10^{-6} \mathrm{~mol} / \mathrm{l}\right)$ in the culture medium. The differentiation of HL 60 cells into mature polynuclear cells following treatment with retinoids is accompanied by a large and rapid increase in galactosyltransferase, fucosyltransferase and neuraminyltransferase activity (45). Moreover, during retinoic acid-induced differentiation of HL 60 cells along the myeloid pathway, there is a marked increase in the activity of protamine kinase and cyclic adeno-

Tab. 2. Materials used by various authors in the study of retinoid-induced differentiation of leukaemic cells.

\begin{tabular}{|c|c|c|c|c|c|}
\hline Authors & Culture medium & $\begin{array}{l}\text { Retinoic } \\
\text { acid } \\
(\mu \mathrm{mol} / \mathrm{l})\end{array}$ & $\begin{array}{l}\text { Length of } \\
\text { treatment } \\
\text { (days) }\end{array}$ & Cell type & $\begin{array}{l}\text { Cell } \\
\text { density } \\
\text { at day } 0 \\
\left(10^{8} / 1\right)\end{array}$ \\
\hline Garg \& Brown (43) & DMEM $10 \%$ FCS*) & 10 & 5 & Murine erythroleukaemic & $1-2$ \\
\hline Flynn et al. (44) & CMRL $10 \%$ FCS & 1 & 8 & $\begin{array}{l}\text { Human leukaemic } \\
\text { promyelocytes }\end{array}$ & 5 \\
\hline Durham et al. (45) & RPMI $164010 \%$ FCS & 1 & 4 & $\begin{array}{l}\text { Promyelocytes } \\
\text { cell line HL } 60\end{array}$ & 1. \\
\hline Fontana et al. (46) & $\begin{array}{l}\text { RPMI 1640-inactivated } \\
\text { FCS }\end{array}$ & $0.1-1$ & 4 & $\begin{array}{l}\text { Promyelocytes } \\
\text { cell line HL } 60\end{array}$ & \\
\hline Durham et al. (47) & RPMI $164010 \%$ FCS & 1 & 5 & $\begin{array}{l}\text { Promyelocytes } \\
\text { cell line HL } 60\end{array}$ & 1 \\
\hline Breitmann et al. (48) & $\begin{array}{l}\text { DMEM + HAM'S F12 } \\
10 \% \text { FCS }\end{array}$ & $0.001-1$ & 5 & $\begin{array}{l}\text { Promyelocytes } \\
\text { cell line HL } 60\end{array}$ & 5 \\
\hline Felsted et al. (75) & RPMI 1640 10\% FCS & 1 & 5 & $\begin{array}{l}\text { Promyelocytes } \\
\text { cell line HL } 60\end{array}$ & $2.5-5$ \\
\hline Olsson \& Breitman (76) & $\begin{array}{l}\text { DMEM + HAM'S F12 } \\
10 \% \text { FCS }\end{array}$ & 1 & 2 to 8 & $\begin{array}{l}\text { Human histiocytic } \\
\text { lymphoma cell line } U 937\end{array}$ & 1 \\
\hline
\end{tabular}

*) $\mathrm{FCS}=$ foetal calf serum 
sine $3^{\prime}, 5^{\prime}$-monophosphate and phospholipid-sensitive calcium-dependent protein kinases (46). Differentiation of HL 60 into granulocytes produces a large increase in the phosphorylation of the various substrates of these enzymes, in particular of protamine by protamine kinase contained in large quantities in these cells (47).

Retinoic acid $\left(10^{-5}\right.$ to $\left.10^{-8} \mathrm{~mol} / \mathrm{l}\right)$ is the principal retinoid used in studies of the differentiation of leukaemic cells. This molecule has been shown to be one hundred times more effective than retinol, retinal and retinyl acetate in studies involving the cell line HL 60 (48). Retinaldehyde all-trans, however, has an effect twenty times greater on murine erythroleukaemic cells. Most of the studies reported here show that the differentiating effect is not related to any cytotoxic phenomenon due to the retinoids (cell viability is not affected by these compounds at the doses used). The effects observed could be mediated by cellular retinoic acid binding protein as in embryocarcinoma cells. However, cellular retinoic acid binding protein has not been detected (49) by various authors although it may be present in the haematopoietic cells considered at levels below the detection threshold of the methods used; other modes of action must therefore be considered.

\section{Melanoma cells}

Melanoma cells are capable, or not, of synthesizing melanin, depending on their degree of differentiation. Meyskens (50) and Lotan (51) showed that following treatment with various retinoids, cultured melanoma cells of both human and murine origin were able to synthesize melanin: on the two cell lines, the human melanoma HS 939 and MIRW, the authors observed an increase in tyrosinase activity and in the quantity of intracellular melanin after seven days of treatment with retinoic acid $10^{-6} \mathrm{~mol} / \mathrm{l}$. In murine melanoma cells $S 91$, in addition to $\beta$-all-trans retinoic acid, other retinoids, such as 13 -cis-retinoic acid and a phenyl analogue augmented melanogenesis. On the other hand, retinyl acetate and palmitate were ineffective. The mechanism of action of retinoic acid would appear to be different from that of melanotropin: following treatment, the intracellular concentration of cyclic AMP does not increase, contrary to what is observed in the presence of melanotropin (52).

Retinoids therefore induce the differentiation of normal and carcinoma cells of various origins. The degree of differentiation observed varies according to the cell line and the nature and concentration of the retinoid used.
Effects of vitamin $A$ and the retinoids on cell proliferation

Normal cells

Yuspa (53) observed an increase in the mitotic index of mouse epidermal cells cultured in the presence of retinyl acetate $\left(3.7 \times 10^{-5} \mathrm{~mol} / \mathrm{l}\right)$. Similarly, retinoic acid $\left(3.3 \times 10^{-5} \mathrm{~mol} / \mathrm{l}\right)$ augments the incorporation of tritiated thymidine into newborn guinea pig epidermal cells (54). The work of Holst \& Oesterhelt (55) shows that when retinol is removed from foetal calf serum by irradiation or gel filtration the growth curve of $3 T 3$ fibroblasts differs little from that of similar cells cultured under normal conditions (MEM + foetal calf serum). On the other hand, other authors have found that retinoic acid $(10 \mu \mathrm{mol} / \mathrm{l})$ inhibits the growth of 3T 3 and 3T 6 fibroblasts by $64 \%$ and $33 \%$ respectively (56). Such discrepancies result from the use of different experimental models.

\section{Cells treated with a tumoural promoter}

Tumoural promoters were defined from work carried out by Berenblum (57) on mouse skin: chemical carcinogenesis takes place according to a two-step model - initiation and promotion. The promoting agents, which induce tumours in initiated cells, stimulate the proliferation of normal cells. Retinyl acetate and retinoic acid both exert an inhibiting effect on the growth of the models studies. Thus, in human lymphocyte cultures treated with tetradecanoylphorbol acetate (TPA) or phorbol dibutyrate (PDB), $A b b$ (58) measured the synthesis of DNA by the incorporation of $\left[{ }^{3} \mathrm{H}\right]$ thymidine in the presence or absence of retinoic acid $\left(3 \times 10^{-6}\right.$ to $\left.3 \times 10^{-4} \mathrm{~mol} / \mathrm{l}\right)$ and observed a $50 \%$ decrease in the incorporation of $\left[{ }^{3} \mathrm{H}\right]$ thymidine in treated cultures approximately ten hours after the addition of the promoter and the retinoic acid.

Tumoural promoters also induce an increase in the activity of cellular ornithine decarboxylase, the key enzyme in the synthesis of composite polyamines which in turn stimulate the synthesis of DNA. Experiments conducted on rat kidney cells (59) and mouse epidermal cells (60) treated with tetradecanoylphorbol acetate show that pretreatment with retinoic acid strongly inhibits cellular ornithine decarboxylase activity.

\section{Transformed cells}

Studies carried out in vitro have shown that the proliferation of transformed cells is inhibited to various degrees in the presence of retinoids (1): table 3 gives various examples which show the complexity of the 
Tab. 3. Growth inhibition by the retinoids in various types of carcinoma cells (1).

\begin{tabular}{|c|c|c|c|}
\hline \multirow{2}{*}{ Cell type } & \multirow{2}{*}{$\begin{array}{l}\text { Histological state of the cell } \\
\text { ( } \mathrm{T}=\text { transformed) }\end{array}$} & \multicolumn{2}{|c|}{ Growth inhibition (\%) } \\
\hline & & Retinoic acid & Retinyl acetate \\
\hline \multicolumn{4}{|l|}{ Mammary cells } \\
\hline $\begin{array}{ll}\text { Mouse: } & \text { adenocarcinoma } \\
\text { Rat: } & \text { adenocarcinoma } \\
\text { Human: } & \text { metastatic breast cancer }\end{array}$ & $\begin{array}{l}\mathrm{T} \text { (spontaneously) } \\
\mathrm{T} \text { (dimethylbenzanthracene) } \\
\mathrm{T} \text { (spontaneously) }\end{array}$ & $\begin{array}{l}50 \\
75 \\
83\end{array}$ & $\begin{array}{l}40 \\
46 \\
57\end{array}$ \\
\hline \multicolumn{4}{|l|}{ Melanoma cells } \\
\hline $\begin{array}{l}\text { Mouse: clone } 2 \text { (S 91) } \\
\text { Human: primary tumour (HS 852) } \\
\text { Human: primary tumour (A 375) }\end{array}$ & $\begin{array}{l}\mathrm{T} \text { spontaneously) } \\
\mathrm{T} \text { (spontaneously) } \\
\mathrm{T} \text { (spontaneously) }\end{array}$ & $\begin{array}{l}83 \\
10 \\
69\end{array}$ & $\begin{array}{l}79 \\
10 \\
48\end{array}$ \\
\hline \multicolumn{4}{|l|}{ Lymphoid cells } \\
\hline $\begin{array}{ll}\text { Mouse: } & \text { lymphoma (BW 147) } \\
& \text { lymphoma (EL 4) } \\
\text { Human: } & \text { Burkitt's lymphoma }\end{array}$ & $\begin{array}{l}T \text { (spontaneously) } \\
\mathrm{T} \text { (benzopyrene) } \\
\mathrm{T} \text { (spontaneously) }\end{array}$ & $\begin{array}{l}58 \\
33 \\
86\end{array}$ & $\begin{array}{l}42 \\
25 \\
68\end{array}$ \\
\hline \multicolumn{4}{|l|}{ Fibroblasts } \\
\hline $\begin{array}{ll}\text { Mouse: } & \text { SV } 373 \\
\text { Human: } & \text { fibrosarcoma (HT 1080) }\end{array}$ & $\begin{array}{l}\mathrm{T}(\mathrm{SV} 40) \\
\mathrm{T} \text { (spontaneously) }\end{array}$ & $\begin{array}{l}10 \\
15\end{array}$ & $\begin{array}{l}10 \\
16\end{array}$ \\
\hline
\end{tabular}

problem since the degree of inhibition varies according to the cell type, the origin of the transformation and the structure of the retinoid used.

\section{Experimental tumours}

In vivo, retinoids reduce the frequency with which various tumours appear after induction with complete carcinogens (azaserine, benzopyrene, dimethylbenzanthracene 'DMBA'). Thus pancreatic tumours appear in the Wistar rat (61) following the intra-peritoneal injection of azaserine and are classified as adenomas, adenocarcinomas and invasive adenocarcinomas: a diet supplemented by various retinoids $(1$ to $2 \mathrm{mmol} / \mathrm{kg}$ of diet) over a one year period causes a reduction in the number of invasive adenocarcinomas. The effect obtained is related to the structure and the dose of the compound used. Retinyl acetate also reduces the rate of mammary adenocarcinoma in Sprague-Dawley rats following two injections of methyl nitrosourea: after 60 days, $37 \%$ of the female rats on a retinyl acetate-supplemented diet had palpable tumours whereas the figure was $91 \%$ in the control group (62). Similarly, etretinate attenuates the tumoural lesions of the skin due to the administration of dimethylbenzanthracene (63). Finally, Verma (64) studied the effect of retinoic acid on mouse skin subjected successively to the action of dimethylbenzanthracene and tetradecanoylphorbol acetate. He observed that the retinoid inhibited the induction of ornithine decarboxylase activity in the epidermal cells.

\section{Mechanisms of action}

The results presented here are often contradictory and show the complexity of the way in which retinoids act. Various experiments have shown that the differentiating role of the retinoids is related to their participation in the biosynthesis of glycoconjugates:

- in vitamin A-deficient rats, the non-differentiation of oligomucous cells into goblet cells is accompanied by a reduction in the synthesis of glycoproteins (17). - Lewis (26) observed that following the supplementation of the culture medium of chondroblasts with retinoic acid and the incorporation of $\left[{ }^{3} \mathrm{H}\right]$ mannose, intercellular contact was maintained. In addition, autoradiography showed that a $M_{\mathrm{r}}=240000$ glycoprotein persisted, whereas it disappeared from untreated cultures.

The mechanism of retinoid action on the biosynthesis of glycoconjugates would appear to be as follows: following the phosphorylation of retinol, the retinyl phosphate thus formed, by analogy with dolichol phosphate, would serve as a monosaccharide acceptor during its glycosylation by a specific glycosyl transferase in the presence of a sugar donor molecule. The synthesis of mannosyl and galactosyl-retinyl phosphate in this way has been demonstrated (65). The mannosyl-retinyl phosphate would then act as the donor of the mannose residue transferred to a glycoprotein acceptor. The ensemble of these reactions, according to Lotan (1), might take place in the cell membrane, thus enabling the glycosylation in situ of the cell surface glycoproteins. However, it should be 
noted that retinol participates more actively in the biosynthesis of glycoconjugates than retinoic acid which does not form retinyl phosphate derivatives (66), although retinoic acid has a stronger differentiating effect than retinol; other mechanisms are thus involved. In addition, the retinoids appear to be involved in the induction of glycosyl transferases (sialyl, fucosyl and galactosyl transferase) and might thus modify the structure of the glycans $(66,67)$. By this mechanism, vitamin A might play a role in the phenomena of recognition and specific combinations between glycan structures. It would also thus be able to modify the behaviour of cells in culture, in particular by increasing cell attachment (68).

Finally, according to Lotan (1), certain specific glycosylation reactions due to the retinoids might modify the affinity of certain cell surface receptors for their ligand: the retinoids could block the proliferation of cells treated by phorbol esters by altering the ligandreceptor affinity (69). However, the treatment of several lines of murine cells with retinoic acid increases epidermal growth factor (EGF) binding by increasing the number of available receptor sites without changing the specificity of the ligand-receptor bond. The retinoids might thus modulate cell growth by a direct interaction with growth-factor receptors (70).

However, the effects of these substances on differentiation and proliferation processes are essentially related to their intracellular metabolism. These molecules bind to a high-affinity receptor present in the cytosol and the ligand-receptor complexes move toward the nucleus. The mechanism of action of the retinoids would appear to be similar to that of the steroid hormones: following nuclear translocation, the complexes bind to protein molecules in particular sites in saturable and specific way. The retinoids are then separated from the binding protein. Bound to the nucleus in this way, they would appear to influence the transcription of cellular DNA by an action on the chromatin $(71,72,73)$. Thus, the human retinoic acid receptor (hRAR) described by Petkovich et al. (12) appears to be a retinoic acid inducible transcriptional enhancer factor like steroid hormone receptors.

Thus, the retinoids are able to modify the activity of various proteiñs. In particular, they might modulate the level of intracellular polyamines by affecting ornithine decarboxylase synthesis. The induction of ornithine decarboxylase occurs in the middle of the G1 phase of the cell cycle: retinoic acid inhibits the induction of the enzyme, at the same time blocking the progression of cells in the G1 phase (74). The retinoids could also regulate cellular metabolism through their interaction with certain protein kinases: the differen- tiating action of retinoic acid on HL 60 cells is correlated with a stimulation of the activity of a protamine kinase and of cyclic AMP- and $\mathrm{Ca}^{2+}$-dependent protein kinases which play a major role in cell proliferation (47).

Vitamin A and its structural analogues therefore appear to act through modifications of transcription and biosynthesis of certain molecules, although we are unable to distinguish clearly between the mechanisms involved in cell differentiation and those involved in proliferation.

At all events, the ability of the retinoids to promote differentiation and to inhibit proliferation is related to their intracellular metabolism; there is however no simple relationship between the number of receptors and the effect of the retinoids (35).

\section{Conclusion}

The biological activity of the retinoids can therefore influence various aspects of cell behaviour, and this occurs by various mechanisms:

1. Vitamin A and/or the retinoids are, in certain cases, essential to the normal process of cell differentiation.

2. They are also capable of inducing the differentiation of various lines of carcinoma cells: murine and human embryonal carcinoma cells cultured in the presence of these compounds are able to differentiate. Similarly, treatment with retinoids brings several lines of leukaemic cells to maturity.

3. The retinoids generally inhibit cell proliferation. The inhibitory effect on the growth of cells treated either by a promoter or a carcinogen is constant. It consists, in the first case, of a reduction in the incorporation of $\left[{ }^{3} \mathrm{H}\right]$ thymidine into cellular DNA and, in the second, of a reduction in the frequency and volume of the tumours. The histological stage of the tumours regresses and the effect is dosedependent.

In summary, vitamin $\mathrm{A}$ and its structural analogues, through poorly-known mechanisms including modifications of genome expression and of certain biosyntheses, are capable of controlling tissue growth and differentiation. This effect is all the more important since it also applies to tumoural cells and thus holds a certain therapeutic interest.

\section{Acknowledgement}

The authors wish to thank David Young for the English translation of the manuscript. 


\section{References}

1. Lotan, R. (1980) Biochim. Biophys. Acta 605, 33-91.

2. Blomhoff, R., Rasmussen, M., Nilsson, A., Norum, K. R., Berg, T., Blaner, W. S., Kato, M., Mertz, J. R., Goodman, D. S., Eriksson, U. \& Peterson, P. A. (1985) J. Biol. Chem. 260, 1360-1365.

3. Goodman, D. S. (1984) In: The Retinoids (Sporn, M. B., Roberts, A. B. \& Goodman, D. S., eds.) vol. 2, pp. $41-88$, Academic Press, Orlando.

4. Blomhoff, R., Norum, K. R. \& Berg, T. (1985) J. Biol. Chem. 260, 1371-1375.

5. Kung, W. M., Geyer, E., Eppenberger, V. \& Huber, P. R. (1980) Cancer Res. 40, 4265-4269.

6. Ong. D. E., Goodwin, M. J., Jesse, R. M. \& Griffin, A. L. (1982) Cancer 49, 1409-1412.

7. Mehta, M. G., Cerny, W. L. \& Moon, R. C. (1980) Cancer Res. 40, 47-49.

8. Palan, P. R. \& Rommey, S. L. (1980) Cancer Res. 40, $4221-4224$.

9. Sklan, D. \& Lotan, R. (1984) Cancer Lett. 22, 41-47.

10. Takase, S., Ong, D. E. \& Chytil, E. (1979) Proc. Natl. Acad. Sci. USA 76, 2204-2208.

11. Mehta, M. G., Cerny, W. L. \& Moon, R. C. (1982) Biochem. J. 208, $731-736$.

12. Petkovich, M.; Brand, N. J., Krust, A. \& Chambon, P. (1987) Nature 330, 444-450.

13. Gubler, M. L. \& Sherman, M. I. (1985) J. Biol. Chem. 17, 9552-9558.

14. Sherman, M. I. (1986) In: The Retinoids and Cell Differentiation (Sherman, M. I., ed.) pp. 162-186, CRC Press Florida.

15. Williams, J. B. \& Napoli, J. L. (1984) Fed. Proc. Fed. Am. Soc. Exp. Biol. 43, 788 (Abstr.).

16. Rojanapo, W., Lamb, A. J. \& Olson, J. A. (1980) J. Nutr. $110,178-188$

17. Olson, J. A., Rojanapo, W. \& Lamb, A. J. (1981) Ann. N. Y. Acad. Sci. 359, $181-191$

18. Marchok, A. C., Cone, M. W. \& Nettesheim, P. (1975) Lab. Inv. 33, 451-461.

19. Hardy, M. H., Sweeny, P. R. \& Bellows, C. G. (1978) J. Ultrastr. Res. 64, 246-260.

20. Yuspa, S. R. \& Harris, C. C. (1974) Exp. Cell Res. 86, 95105.

21. Harris, C. C., Sporn, M. B., Kaufman, D. G., Smith, J. M., Frank, B. A., Jackson, F. E. \& Saffiotti, U. (1972) J. Natl. Cancer Inst. 48, 743-761.

22. Hayes, K. C., Nielsen, S. W. \& Eaton, H. D. (1968) Arch. Ophtalmol. 80, 771-787.

23. Howell, J. M. \& Thompson, J. N. (1967) Br. J. Exp. Pathol. $48,450-454$.

24. Sporn, M. B., Dunlop, N. M., Newton, D. L. \& Henderson, W. R. (1976) Nature 263, 110-113.

25. Dingle, J. T., Horsfield, P., Fell, M. B. \& Barratt, M. E. J. (1975) Ann. Rheum. Dis. 34, 303-311.

26. Lewis, C. A., Pratt, R. M., Pennypacker, J. P. \& Hassell, J. R. (1978) Dev. Biol. 64, 31-47.

27. Pennypacker, J. P., Lewis, C. A. \& Hassel, J. R. (1978) Arch. Biochem. Biophys. 186, 351-358.

28. Slack, J. M. W. (1987) Nature 327, 553-554.

29. Saunders, J. W. \& Gasseling, M. T. (1968) In: Epithelial Mesenchymal Interactions (Fleischmayer, R. \& Billingham, R. E., eds.) pp. 78-97, Williams and Wilkins, Baltimore.

30. Thaller, C. \& Eichele, G. (1987) Nature 327, 625-628.

31. Sherman, M. I., Gubler, M. L., Barkai, U., Harper, M. J., Coppola, G. \& Yuan, J. (1985) In: Retinoids, Differentiation and Disease (Ciba Found. Symp.) vol. 113, pp. 42-60, Pitman, London.
32. Strickland, S. \& Mahdavi, V. (1978) Cell 25, 393-403.

33. Plet, A. \& Evain, D. (1982) J. Biol. Chem. 257, 889-893.

34. Wang, S. \& Gudas, L. J. (1983) Proc. Natl. Acad. Sci. USA $80,5880-5887$.

35. Eriksson, U., Hansson, E., Nilson, 'M. J., Josson, K. H., Sundelin, J. \& Peterson, P. A. (1986) Cancer Res. 46, $717=$ 722.

36. Griep, A. E. \& DeLuca, H. F. (1986) Proc. Natl. Acad. Sci. USA $83,5539-5543$.

37. Jetten, A. M., Jetten, M. E. R. \& Sherman, M. I. (1979) Exp. Cell Res. 124, 381 - 391 .

38. Sherman, M. I., Matthaei, K. I. \& Schlinder, J. (1981) Ann. N. Y. Acad. Sci. 359, 192-199.

39. Sherman, M. I., Paternoster, M. L. \& Taketo, M. (1983) Cancer Res. 43, 4283-4290.

40. Speers, N. C. (1982) Cancer Res. 42, 1843-1849.

41. Barkai, U. \& Sherman, M. I. (1987) J. Cell Biol. 104, 671 678.

42. Andrews, P. W. (1984) Dev. Biol. 103, 285-293.

43. Garg, L. C. \& Brown, J. C. (1983) Differentiation 25, $79-83$.

44. Flynn, P. J., Miller, W. J., Weisdorf, D. J., Arthur, D. L., Brunning, R. \& Branda, R. F. (1983) Blood 62, 1211 1217.

45. Durham, J. P., Ruppert, M. \& Fontana, J. A. (1983) Biochem. Biophys. Res. Commun. 110, 348-355.

46. Fontana, J. A., Reppucci, A., Durham, J. P. \& Miranda, D. (1986) Cancer Res. 46, 2468-2473.

47. Durham, J. P., Butcher, F. R. \& Fontana, J. A. (1982) Biochem. Biophys. Res. Commun. 108, 840-845.

48. Breitman, T. R., Selonick, S. E. \& Collins, S. J. (1980) Proc. Natl. Acad. Sci. USA 77, 2936-2940.

49. Douer, D. \& Koeffler, H. P. (1982) J. Clin. Invest. 69, 277283.

50. Meyskens, F. L. \& Fuller, B. B. (1980) Cancer Res. 40, 2194-2196.

51. Lotan, R., Neumann, G. \& Deutsch, V. (1983) Cancer Res: $43,303-312$.

52. Lotan, R. \& Lotan, D. (1981) J. Cell Physiol. 106, 179191.

53. Yuspa, S. H., Eigjo, K., Morse, M. A. \& Wiebel, F. J. (1977) Chem. Biol. Interact. 16, 251-264.

54. Christophers, E. (1974) J. Invest. Dermatol. 63, 450-455.

55. Holst, A. \& Öesterhelt, D. (1983) Hoppe-Seyler's Z. Physiol. Chem. 364, 563-573.

56. Jetten, A. M., Jetten, M. E. R., Shapiro, S. S. \& Poon, S. P. (1979) Exp. Cell Res. 119, 289-299.

57. Berenblum, I. (1941) Cancer Res. 1, 44-48.

58. Abb, J. \& Reinhart, F. (1980) Int. J. Cancer 25, 267-271.

59. Paranpje, M. S., Delarco, J. E. \& Todaro, G. J. (1980) Biochem. Biophys. Res. Commun. 94, 586-591.

60. Lichti, U., Patterson, E., Hennings, H. \& Yuspa, S. H. (1981) Cancer Res. 41, 49-54.

61. Longnecker, D. S., Curphey, T. J., Kuhlmann, E. T. \& Roebuck, B. D. (1982) Cancer Res. 42, 19-24.

62. Thompson, H. J., Becci, P. J., Brown, C. C. \& Moon, R. C. (1979) Cancer Res. 39, 3977-3980.

63. Mori, M. \& Kobayashi, K. (1981) Cell. Mol. Biol. 27, 27-37.

64. Verma, A. K., Conrad, E. A. \& Boutwell, R. K. (1980) Carcinogenesis 1, 607-611.

65. Shidoj, Y., Sasak, W., Silverman-Jones, C. S. \& DeLuca, L. M. (1981) Ann. N. Y. Acad. Sci. 359, 345-357.

66. Reiss, M., Maniglia, C. A. \& Sartorelli, A. C. (1985) Cancer Res. 45, 20ソュ-2097.

67. Gmeimer, B. M. K. (1986) Biochim. Biophys. Acta 856, $392-394$ 
68. Desmoulins, D., Aussel, C., Cals, M. J., Agneray, J. \& Ekindjian, O. G. (1986) Cell Biol. Int. Rep. 10, 501-508.

69. Driedger, P. E. \& Blumberg, P. M. (1980) Proc. Natl. Acad. Sci. USA 77, $567-571$.

70. Jetten, A. M. (1980) Nature 284, 626-629.

71. Liau, G., Ong, D. E. \& Chytil, F. (1985) Arch. Biochem. Biophys. 237, 354-360.

72. Ferrari, N. \& Vidali, G. (1985) Eur. J. Biochem. 151, $305-$ 310.
73. Jardillier, J. C. \& Rallet, A. (1986) Bull. Cancer 73, $180-$ 192.

74. Haddox, M. K. \& Russell, D. H. (1979) Cancer Res. 39, 2476-2480.

75. Felsted, R. L., Gupta, S. K., Glover, C. J., Fischkoff, S. A. \& Gallagher, R. E. (1983) Cancer Res. 43, 2754-2761.

76. Olsson, I. L. \& Breitman, T. R. (1982) Cancer Res. 42, 3924-3927.

Docteur Marie-Josèphe Cals

Laboratoire de Biochimie

Hôpital Corentin-Celton

37 boulevard Gambetta

F-92133 Issy-les-Moulineaux 
